\title{
The effect of achievement motivation and expectation toward students' learning achievement on Islamic education
}

\author{
Nurul Hidayati \\ nurulhidayati5@yahoo.co.id \\ SMP N 1 Kota Salatiga \\ DOI: $10.18326 /$ mudarrisa.v9i2.208-227
}

\begin{abstract}
This research aims at figuring out the effect of students' achivement motivation and expectation towards students' learning achivementa t PAI subject at VII class in junior high school level in 2014. There were three schools involved in the research: SMP N 1 Salatiga, Salatiga SMP N 6, and SMP Muhammadiyah Salatiga. This is quantitative research with purposive sampling technique. The data collecting technique were questionnaires, test and documents. Questionnaires were to see the relation between students' achievement motivation and expectation while test was used to gain data for learning achievement on PAI. The instruments for questionnaire were tested using validity and reliability test, normality test, autocorrelation test, $\mathrm{F}$ test, and coefficient determinant test. The data analysis used regression techniques. The findings of the research show that independent variables of achievement motivation $\left(\boldsymbol{X}_{\mathbf{1}}\right)$ and expectations $\left(\boldsymbol{X}_{\mathbf{2}}\right)$ influence the dependent variable of learning achievement $(\mathrm{Y})$ by $\mathrm{Y}^{\prime}=48.866+0.04 \boldsymbol{X}_{\mathbf{1}}+0.258 \boldsymbol{X}_{\mathbf{2}}$. This implies that 1 value of achievement motivation and 1 value of exectation will result on 49.164 learning achievement in PAI subject.
\end{abstract}

\section{INTRODUCTION}

Education is one of the fundamentals and strategic items in a nation's development. To achieve the goal, human resource development is a 
massive demand in the field. In Islam, there is a concept teaching on the balance of activity and initiative; later known as jihad and ikthiar. This is in line as what is written in Qs. An Najm verses 39 - 41:

$$
\text { و أن ليسن للإِ نسان إلاماسعى (39) (41) وأنّ سعيه سوف يرى (40) }
$$

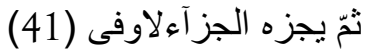

And that man hath only that for which he maketh effort, And that his effort will be seen. And afterward he will be repaid for it with fullest payment

Teaching and learning developed in the schools shall embrace confident and learning habit as continuous and lifelong principles, in purpose of promoting the society and growing creativity and innovativeness to deal with the future. In teaching, furthermore, teacher should consider every student's ability as every student may have different talent and ability.

Choosing suitable procedure matching all level of students' ability is impossible as students are different. In choosing the procedure, then, teacher should consider students 'abilities, interests, and achievements. Dealing with less-able-student, teachers are encouraged to teach with love and sincerity. In the other hand, teachers may create special programs to deal with strong students. Motivation is the driving force to do something. Achievement motivation is one of factors affecting students' success. Achievement motivation will put students in a condition of willing to do something. This is the heart of teaching and learning process. Higher motivation will lead to perseverance in learning. Yet, low motivated students will feel constrained in studying, leading to less maximal achievement. 
Besides motivation, students' expectation and desire on how teacher act in the class are also affecting the smoothness of teaching and learning process. If teacher could meet the expectations, then students will learn calmly, passionately, and full of motivation. Contrary, if they do not meet their expectations, student will be disappointed and frustrated. Every individual has a need for achievement both within the school and community as a form of to prove existence and quality in the presence of others. That achievement is the benchmark of personal qualities in his field. Learning achievement is believed as of the students' success. This kind of achievement gives positive impacts on students' existence before their friends and teachers; the underachievers in the contrary face different fact.

There are actually positive and negative impact on class division based on the level of students achievements. In positive, Islamic Education (Pendidikan Agama Islam) teachers will easily manage the teaching and learning processes, students will be motivated in studying and there is competition to be the best in class. However, lower level students will have passive and static class, less motivated and some disobedient in the class are some examples of negative side. Among 4.704 SMP/ MTs in Salatiga, the result of National Examination showed that SMP N 1 Salatiga ranked as the 14th (upper level), SMP N 6 Salatiga was in the middle (1.712nd) and SMP Muhammadiyah Salatiga ranked at 3.001st (or in the lower level. 


\section{Mudarrisa: Jurnal Kajian Pendidikan Islam, Vol. 9, No. 2, 2017}

\section{Achievement Motivation}

Motivation is firstly introduced by McClelland by "N-Ach", meaning Need for Achievement, as the needs to achieve (Haditomo, 1979:8). Later in the development, motivation theories earned attentions from psychologist as they saw that motivation was important in human life. Finally, they created theories about learning motivation and achievement motivation.

People usually called motivation by motive, encouragement or need. They are however sharing the same principle. Motivation can be defined as needs, impulse goals, incentives, conflicts and the need for achievement and strength (Beck, 1990:2). This implies that motivation is the impulses or stimulations to behave in certain ways to reach certain goals.

Motivation in achievement can also be influenced by the tendency to seek competition and realizing abilities. In a good and proper educational system, learning has an active and focused nature embodied in the form of clear and operational instructional goals, high and low, big and small, and responsive intensity depending on the level of physical, mental and learning maturity, all happening because of the use of learning resources.

Learning resources are various or all sources either in the form of data, people and certain forms that can be used by students in learning either separately or combined so as to facilitate students in achieving learning objectives (Sardiman, 1989:141). Teachers also have an important role in developing the success of their students. However, in our society, it 
is still common to find example, teachers often giving more encouragement to male students to pursue success compared to female ones.

Psychologists such as Carol Dweek and Therese Goetsz conclude that teachers have tendencies to criticize female students who gain high achievement on tasks requiring some intelligence. In the other hands, they tend to punish male students who are underachievers and less motivated. There was assumption stating that if male students were successful in their tasks, they were likely to more have a care and hard worker. To women, if they were fail in doing the task, they tended to blame themselves due to the incapability and less intelligent (Davidoff, 1991:40).

H.J.M. Hermans mentions some characteristics of a responsible and good achivement motivation person as the following:

- S/he tends to do challenging learning tasks-those which are above her/his ability level.

- S/he wants to work and try by her/his own without always being helped by teachers.

- A strong will to move forward and seek for higher achievement-a little bit higher than what she/he has earned in the past.

- Future oriented, learing is always seen as the way to pursue all of the dreams.

- In choosing working friends, s/he chooses friends based on the ability to finish the task given by the teachers, not for sympathy or other personal feelings.

- Persistency in facing troubles (Winkel, 1996:97-98). 
Talented students are excellence achievers in some subjects. They, then, considered as fast learners and potentially have abilities to face complex materials. These students are also seen as having different level of steadiness compared to their friends in the class which may cause them to be more relaxed in learning. This condition is dangerous ones as they may have less motivation to explore which may lead them to receive learning outcome far under their real capacities.

From various explorations above, author sums up the following as the characteristics or indicators of achievement motivations:

- Tendency to work on challenging PAI tasks but the results do not reflect the real ability.

- Love to spend spare times in a positive ways and work hard based on personal drives.

- Strong willingness to reach higher achivement compared the previous ones.

- Future oriented and consider studying the key for success.

- Choosing friends based on their abilities, not based on sympathy.

- Persistency in learning and facing problems.

- Follow rules and have faith in religion.

- Active in religious activities in the neighborhood.

\section{Expectation}

Students are learning person with human resources which could be improved and developed. One of the way is through education where students could gain knowledge, technologies (Iptek), and have faith to Allah (Imtaq). Iptek and Imtaq are believed as a valuable aid to help human 


\section{Mudarrisa: Jurnal Kajian Pendidikan Islam, Vol. 9, No. 2, 2017}

fulfill his needs in this world today and hereafter. Dealing with human needs, Maslow proposed a theory mentioning that there were two types of needs: basic needs and Meta needs. Basic needs involves needs of food, love, security, and pride. Meta needs in the other hands cover justices, unity, goodness, orderliness and beauty (Sriyanti, 2009:100). Students who do not get their basic needs (security and love) will have a very small psychological energy to study. If he has been secured and loved or gather attention from the teacher, he will eventually feel the energy to study more. Expectation is there when that needs are not completed.

Riduwan (2005) argues that "ekspektasi adalah suatu kesempatan yang diberikan, terjadi karena perilaku untuk tercapainya tujuan". In other hand, expectations are a given opportunity, occurring because of the behavior to achieve the goal. Students may have expectations toward their teachers as teachers are role model for students in which everything done by teachers will be followed by their students at school. Expectations and wishes of students towards the treatment of teachers in schools will affect the smoothness of the learning process. If expectations are met, then students will learn calmly, passionately, and full of motivation. Conversely, if expectations are not met, then the learning process will be hampered, or will cause disappointment or frustration.

Expectancy theory proposed by Victor H. Vroom in Gibson explains that people or employees will be motivated to work or do certain things, if they believe that they will get big reward. He further explains that "Motivation as a process governing choices among alternative form of Voluntary 
activity, in his view, most behaviors are under the voluntary activity. In his view, most behaviors are under the voluntary control of the person and are consequently motivated" (Gibson, 1994:147).

Motivation as a process of choice management among a number of alternative work activities, behavior is in the control of the individual and through which the individual is motivated. Greenberg argues that theory expectancy asserts that people are motivated to work when they expect that they will be able to achieve the things they want from their jobs. Expectancy theory characterizes people as rational beings who think about what they have to do in rewarded and how much the reward means to them before they perform their jobs (Greenberg, 2011:55).

From the elaboration above, author could elaborate the indicators of expectations as the following:

- Feeling the needs and hopes on the importance of education.

- Having the psychological energy to study.

- Feeling comfortable when loved and cared for by the teacher

- Having a keenness to be treated well by teachers at school

- Having a sense of calm, spirit, and full of motivation when in school

\section{Learning Achievements in Islamic Education (PAI) Subject}

Learning achievement in Pendidikan Agama Islam (PAI) or Islamic Education Subject is results achieved by students in performing a complex activity (learning activities) with the changes behavior as a result of interaction between stimulus and response in the form of skills, attitudes, 
habits, intelligence or a sense expressed in the form of symbols, numbers, letters and sentences on Islamic education subjects (PAI).

\section{RESEARCH METHODOLOGY}

This research took place at: SMP Negeri 1 Salatiga Jl. Kartini No. 24 Salatiga, SMP Negeri 6 Salatiga Jl. Tegalrejo Salatiga, and SMP Muhammadiyah Salatiga Jl. Cempaka No. 5-7 Salatiga. The time of the research was from April-June 2014. This is quantitative research which is defined as a research method based on philosophy of positivism, used to examine in a particular population or sample, sampling technique used is generally random sampling, data collection uses research instrument, and the data analysis serves quantitative data / statistics data analysis aiming at testing the hypothesis.

Quantitative research is used to find the interactive relation which is relationships affecting two or more variables. This research will try to see the relation between achievement motivation and expectation towards learning achievement on PAI subject at VII class of excellent class in Junior High School level in 2014 (Field research at SMP N 1 Salatiga, SMP N 6 Salatiga, dan SMP Muhammadiyah Salatiga).

The population in this research is the students of excellent class in VII grade of SMP N 1 Salatiga, SMP N 6 Salatiga, dan SMP Muhammadiyah Salatiga; the sample is from VII grade excellent class from SMP N 1 Salatiga, SMP N 6 Salatiga, dan SMP Muhammadiyah Salatiga. The sampling technique is purpose cluster random sampling which is 
specific sampling technique taking into accounts traits or specific characteristics that are thought to be closely related to the characteristics or traits that exist in a previously known population. Purposive sampling technique is used to choose or decide the students. Cluster random sampling is used to randomly choose the students at VII grade. It is through the lottery system.

Selection of appropriate data collection techniques is needed in a study. If the technique is inappropriate, the data gathered will not be reflecting the results of the research. Research instruments employed are: 1) questionnaire, it used to gather data for first free variable $\left(X_{1}\right)$ namely achievement motivation and for second free variable $\left(\mathrm{X}_{2}\right)$ which is expectation; 2) test, it is used to get data on students' learning achievement in PAI subject; and 3) documentation which covers information about students lists, curriculum, lesson plan and PAI syllabus.

This research employed some tests; the tests for the instruments were validity and reliability. Classic assumption test was used to see whether regression model really showed the significant and representative relation. Those tests are Normality Test, Autocorrelation Test, F Test (Test Simultaneously), Test R2 (Coefficient of Determination). Technique of analyzing the data employed multiple linear regressions.

\section{RESULTS AND DISCUSSION}

Achievement Motivation Instrument Test Results 
Table 1 shows that questionnaire item number 2 is score 0.02 (under 0.30). This item was invalid and then excluded from the questionnaire. So the questionnaire used was only consisted of 29 items. Table 2 shows the reliability value of achievement motivation variable.

Table 1. Results of Achievement Motivation Instrument Test

\begin{tabular}{cccc}
\hline No & Test Items & Value & Explanation \\
\hline 1. & Item no 1 & 0.38 & Valid \\
2. & Item no 2 & 0.02 & Invalid and excluded \\
3. & Item no 3 & 0.66 & Valid \\
4. & Item no 4 & 0.66 & Valid \\
5. & Item no 5 & 0.62 & Valid \\
6. & Item no 6 & 0.42 & Valid \\
7. & Item no 7 & 0.42 & Valid \\
8. & Item no 8 & 0.60 & Valid \\
9. & Item no 9 & 0.62 & Valid \\
10. & Item no 10 & 0.61 & Valid \\
11. & Item no 11 & 0.67 & Valid \\
12. & Item no 12 & 0.78 & Valid \\
13. & Item no 13 & 0.77 & Valid \\
14. & Item no 14 & 0.45 & Valid \\
15. & Item no 15 & 0.81 & Valid \\
16. & Item no 16 & 0.56 & Valid \\
17. & Item no 17 & 0.62 & Valid \\
18. & Item no 18 & 0.64 & Valid \\
19. & Item no 19 & 0.70 & Valid \\
20. & Item no 20 & 0.74 & Valid \\
21. & Item no 21 & 0.74 & Valid \\
22. & Item no 22 & 0.54 & Valid \\
23. & Item no 23 & 0.70 & Valid \\
24. & Item no 24 & 0.36 & Valid \\
25. & Item no 25 & 0.41 & Valid \\
26. & Item no 26 & 0.66 & Valid \\
27. & Item no 27 & 0.85 & Valid \\
28. & Item no 28 & 0.41 & Valid \\
29. & Item no 29 & 0.70 & Valid \\
30. & Item no 30 & 0.46 & Valid \\
\hline & & \\
\hline
\end{tabular}

In table 2 , the test shows reliability score was 0.92 , meaning that the questionnaire was reliable. This can be concluded that the questionnaire 
consisting of 29 items were valid and reliable to measure the achievement motivation.

Table 2 . The result of reliability analysis

\begin{tabular}{ll}
\hline Reliability analysis - scale (alpha) & \\
Reliability coefficients & $: 20.0$ \\
\hline N of Cases & $: 30$ \\
N of Items & $: 0.92$ \\
Alpha & \\
\hline
\end{tabular}

\section{Results of Expectation Instrument Test}

The validity results of expectation instrument are presented in Table 3.

Table 3. Result of expectation instrument test

\begin{tabular}{cccc}
\hline No & Test Item & Value & Explanation \\
\hline 1. & Item no 1 & 0.63 & Valid \\
2. & Item no 2 & 0.59 & Valid \\
3. & Item no 3 & 0.72 & Valid \\
4. & Item no 4 & 0.63 & Valid \\
5. & Item no 5 & 0.58 & Valid \\
6. & Item no 6 & 0.62 & Valid \\
7. & Item no 7 & 0.44 & Valid \\
8. & Item no 8 & 0.53 & Valid \\
9. & Item no 9 & 0.67 & Valid \\
10. & Item no 10 & 0.17 & Invalid and revised \\
11. & Item no 11 & 0.87 & Valid \\
12. & Item no 12 & 0.51 & Valid \\
13. & Item no 13 & 0.89 & Valid \\
14. & Item no 14 & 0.69 & Valid \\
15. & Item no 15 & 0.73 & Valid \\
16. & Item no 16 & 0.45 & Valid \\
17. & Item no 17 & 0.69 & Valid \\
18. & Item no 18 & 0.67 & Valid \\
19. & Item no 19 & 0.86 & Valid \\
20. & Item no 20 & 0.88 & Valid \\
21. & Item no 21 & 0.68 & Valid \\
22. & Item no 22 & 0.55 & Valid \\
23. & Item no 23 & 0.46 & Valid \\
24. & Item no 24 & 0.70 & Valid \\
\hline & & &
\end{tabular}




\begin{tabular}{lccc}
\hline 25. & Item no 25 & 0.63 & Valid \\
26. & Item no 26 & 0.22 & Invalid and revised \\
27. & Item no 27 & 0.72 & Valid \\
28. & Item no 28 & 0.67 & Valid \\
29. & Item no 29 & 0.80 & Valid \\
30. & Item no 30 & 0.63 & Valid \\
\hline
\end{tabular}

The table reflects that item number 10 was valued 0.16 (under 0.30 ) and item no 26 was valued by 0.22 (under 0.30 ); they were invalid and then excluded. The questionnaire used later consisted only by 28 items. The reliability result of expectation variable is shown in Table 4 .

Table 4. Results of reliability test of Expectation variable

\begin{tabular}{ll}
\hline Reliability analysis - scale (alpha) & \\
Reliability coefficients & \\
\hline N of Cases & $: 20.0$ \\
N of Items & $: 30$ \\
Alpha & $: 0.95$ \\
\hline
\end{tabular}

Table 4 shows that the result is 0.95 meaning that the 28 items were reliable. To conclude, the expectation questionnaire consisting of 28 items were valid and reliable.

\section{Description of Research Results}

There were $77(\mathrm{~N})$ students participating in filling out the questionnaire of achievement motivation, with 106.43 for the average, 106.00 for median, 99 for mode, 11.83 for deviation standard, 139.85 for value for variance, and 8195.00 for the total value. For expectation questionnaire, there were 77 students $(\mathrm{N})$ participating with 116.13 for average, 115.00 for the median105 for the mode, 11.84 for deviation standard, 140.17 for variance value, and 8942.00 for the total. The statistics for learning 


\section{Mudarrisa: Jurnal Kajian Pendidikan Islam, Vol. 9, No. 2, 2017}

achievement is there were 77 students participating in the research with 82.29 for the average, 82.00 for median, 80.00 for the mode, 5.58 for the deviation standard and the total was 6431.00 .

Normality testing as one of the Classic Assumption Test shows that the Z K-S value for achievement motivation is 0.47 by asymp sig 0.98 . This value is bigger that 0.05 meaning the motivation variable is normally distributed. In expectation, the $Z$ value is 0.74 by asymp sig of 0.64 , which is higher than 0.05 . This shows that the variable of expectation is normally distributed. $Z$ value for PAI learning achievement is 1.34 by asymp sig of 0.06. The value is higher than 0.05 which means that the variable is normally distributed. To sum up, all the three variables are normally distributed.

The results of auto-correlation test are actually the same with the result for multiple regression. Yet, for the sake of autocorrelation test, the thing to focus is on the Durbin-Watson score. The indicator is if the value of Durbin-Watson set in between 2-4 (for 5\% significant level), there is no autocorrelation. If the value, in other hands, is not in $2-4$, this means there can be autocorrelation or the relation cannot be determined. After the computation, the value of Durbin-Watson is 1.11 in which this value is not in between 2-4. This can be concluded that there is autocorrelation or cannot be determined relation in the equation variable of learning achivement towards motivation and expectation.

There are actually so many analyses that could be drawn from the $\mathrm{F}$ Test. Yet, for the purpose of linearity testing, deviation from linearity is 
the only focus. The rule is if sig F value is less than 0.05 , the relation is not linear. If the sig $\mathrm{F}$ value is higher than 0.05 , the relation is linear. The $\mathrm{F}$ value resulted from the computation is 0.72 by sig value of 0.84 . This sig value is higher than 0.05 meaning that the relation between learning achievement in PAI and motivation is linear. Another F test is done to see the relation between learning achievement and expectation showing that the $F$ value is 0.78 by sig value of 0.77 . The sig value is higher than 0.05 which means that the relation is linear.

$\mathrm{R}^{2}$ testing or Coefficient Determination testing is used to see the value of motivation coefficient determination towards the learning achievement. The $\mathrm{R}$ Square value is 0.22 . This means that motivation can explain as $22 \%$ for the variations in PAI learing achievement. In simpler way, the amount of contribution of achievement motivation to the achievement of Islamic Education (PAI) is $22 \%$, the rest (78\%) comes from other variables. Further, the R Square for expectation is 0.37 . This means that the amount of contribution of expectation to the achivement of Islamic Education (PAI) is 37\% while the other 63\% comes from other variables.

\section{Data Analysis}

The profile for free variable one $\left(\mathrm{X}_{1}\right)$ namely motivation is as the following:

Table 5. Achievement Motivation Profile

\begin{tabular}{ccccc}
\hline No & Value Interval & Total & Percentage & Explanation \\
\hline 1 & $84-104$ & 32 & $42 \%$ & Low \\
2 & $105-125$ & 38 & $49 \%$ & Medium \\
3 & $126-146$ & 6 & $9 \%$ & High \\
\hline
\end{tabular}


The profile for free variable one $\left(\mathrm{X}_{2}\right)$ namely expectation is as the following:

Table 6. Expectation Profile

\begin{tabular}{ccccc}
\hline No & Value Interval & Total & Percentage & Percentage \\
\hline 1 & $89-106$ & 19 & $19 \%$ & Low \\
2 & $107-124$ & 40 & $52 \%$ & Medium \\
3 & $125-142$ & 18 & $23 \%$ & High \\
\hline
\end{tabular}

The profile for dependent variable (Y) namely learning achievement for PAI is as the following:

Table 7. PAI Learning Achievement Profile

\begin{tabular}{lllll}
\hline No & Value Interval & Total & Percentage & Percentage \\
\hline 1 & $74-81$ & 38 & $50 \%$ & Low \\
2 & $82-88$ & 21 & $27 \%$ & Medium \\
3 & $89-96$ & 18 & $23 \%$ & High \\
\hline
\end{tabular}

\section{DISCUSSION}

Analysis using SPSS 10 shows the relation between achievement motivations $\left(\mathrm{X}_{1}\right)$ with expectation $\left(\mathrm{X}_{2}\right)$ is positive relation at the point of 0.685. This means that this relation is at high level (high correlation is indicated by value from $0.6-0.8)$. The higher the motivation a student has, the higher is the expectation. In contrary, the lower the motivation a student has, the lower is the expectation. Motivation a student has from inner drives will lead him to have a bigger expectation which later on will help him achieving their dreams. Using the same tool, motivation $\left(\mathrm{X}_{1}\right)$ affects positively to the dependent variable of PAI learning achievement (Y). From the calculation of: $Y^{\prime}=59.98+0.22 \mathrm{X}$, students with 1 value of motivation will have score 60.198 in the PAI learning achievement. 
Students with high motivation will have high learning outcome. It applies vice versa.

SPPS 10 computation shows that the expectation $\left(X_{2}\right)$ is significantly affect the learning achievement of PAI (Y) in a positive way. From the regression computation using the formula of $\mathrm{Y}^{\prime}=50.00+0.29$ $\mathrm{X}$, it can be concluded that having 1 value of expectation will cause students to have score of 50.29 in PAI. It implies that the higher the expectation is the higher the score the students can achieve; and vice versa. The next computation is to see the effect of motivation $\left(\mathrm{X}_{1}\right)$ and expectation $\left(\mathrm{X}_{2}\right)$ to the dependent variable of learning achievement $(\mathrm{Y})$. Using SPSS 10 to see the multiple regression computation of $Y^{\prime}=48,87+$ $0,04 \mathrm{X}_{1}+0,26 \mathrm{X}_{2}$, it can be seen that having 1 value of motivation and 1 value of expectation will cause students to gain 49.16 at PAI learning achievement.

\section{CONCLUSIONS}

This research concludes that profile of first independent variable (X1) that is achievement motivation and second free variable (X2) that is expectation with dependent variable (Y) that is learning achievement of Islamic Religious Education (PAI) is 1. Students with low level of achievement motivations were 32 students (or $42 \%$ ), those in the middle level were 38 or $49 \%$ and students with high level of achievement motivation were 6 students with 9\%. 2. Students having low expectation were 19 students (19\%), middle level of expectations hit 40 students (52\%) and students 
with high expectations were 18 students (23\%). 3. There were $50 \%$ or 38 students were having low learning achievement, $27 \%$ or 21 students were in the middle level and 18 students or $23 \%$ were at the high level of achievement.

There was positive correlation between achivement motivation $\left(\mathrm{X}_{1}\right)$ and expectation $\left(\mathrm{X}_{2}\right)$ by 0.69 of correlation coefficient. Students with higher achievement motivation are likely to have higher expectation. Meanwhile, students with lower achievement motivation will have lower expectation. There was also relation between achievement motivation $\left(\mathrm{X}_{1}\right)$ and expectation $\left(\mathrm{X}_{2}\right)$ to $\mathrm{Y}$ dependent variable namely PAI learning achievement using multiple regression equation: $\mathrm{Y}^{\prime}=48.87+0.04 \mathrm{X}_{1}+$ $0.26 \mathrm{X}_{2}$. This implies that for 1 value of achivement motivation and 1 value of expectation will result on 49.16 of learning achievement in Islamic Education (PAI). Students with higher motivation and expectation are likely to have higher learning achievement and vice versa.

This research finally suggests three things: 1) the students are suggested to increase the level of motivation and the expectation due to the fact that they would increase the learning achievement in Islamic Education (PAI). 2) The school, especially the Headmaster, the Deputy Head of Curriculum and the PAI teachers are expected to create such as policies in improving the students' achievement motivation and expectation as this results high scores on PAI. 3) Other researchers are expected to find other variables affecting learning achievement in PAI; 
they can start by including learning interest, educational backgrounds and parents' incomes.

\section{References}

Al-Saibany, O. M. A. (1979). Falsafah Pendidikan Islam. Jakarta: Bulan Bintang.

'Ali, S. I. (2006). al-Fikr al-Tarbawi al-Islami wa Tahaddiyat al-Mustaqbal, alQahirah: Dar al-salam.

Arikunto, S. (1998). Prosedur Penelitian. Jakarta: Rineka Cipta.

Azwar, S. (2003). Reliabilitas dan Validitas. Yogyakarta: Pustaka Pelajar.

Beck, R. C. (1990). Motivation: Theories and Principles. Engliwood Clifft, New Jersey: Prentice Hall Inc.

Gunarsa, S.D. (1985). Berbagai Alternatif Pelayanan Pendidikan Anak Berbakat Luar Biasa, dalam buku, Anak-Anak Berbakat, Pembinaan dan Pendidikannya. Jakarta: Rajawali Pers.

Haditomo, S. R. (1979). Achievement Motivation, Parent Educational Level and Child Reading Practice in Four Occupational Groups. Yogyakarta: UGM Press.

James, W. P. \& Baker, E. I. (1981). Bagaimana Mengajar Secara Sistematis. Yogyakarta: Yayasan Kanisius.

Kock, H. (1981). Saya Guru Yang Baik. Yogyakarta: Kanisius.

Raharjo, R. (2010). Inovasi Kurikulum Pendidikan Agama Islam, Yogyakarta: Magnum Pustaka.

Sardiman, A. M. (1994). Interaksi dan Motivasi Belajar Mengajar Pedoman bagi Guru dan Calon Guru. Cet. Ke-5, Jakarta: Raja Grafindo Persada.

Sardiman, Arief Sukadi, Radikun, Sujarwo, S. (1989). Beberapa Aspek Pengembangan Sumber Belajar. Ed. I, Cet. I, Jakarta: Medyatama Sarana Prakarsa.

Slameto. (1991). Belajar dan Faktor-Fakor yang Mempengaruhi. FKIP UKSW Salatiga, Cet-2, Jakarta: Rineka Cipta.

Sriyanti, L, et.al. (2009). Teori-Teori Belajar. STAIN Salatiga Pres. 
Mudarrisa: Jurnal Kajian Pendidikan Islam, Vol. 9, No. 2, 2017

Sugiyono. (2011). Metode Penelitian Kuantitatif, Kualitatif, dan REBB. Bandung: AFABETA.

Sulaiman, W. (2004). Analisis Regresi Menggunakan SPSS, Contoh Kasus dan Pemecahannya. Yogyakarta: Andi.

Winkel, W. S. (1987). Psikologi Pengajaran. Jakarta: PT. Gramedia.

Winkel, W. S. (1996). Psikologi Pembelajaran. Jakarta: PT. Gramedia.

Winkel, W. S. (1983). Psikologi Pendidikan dan Evaluasi Belajar. Jakarta: PT. Gramedia.

Zuhaerini. (1983). Metodik Khusus Pendidikan Agama. Surabaya: Usaha Nasional. 